\title{
Note on References, Texts, and Quotations
}

Textual references in this study are drawn from The Faerie Queene, ed. A. C. Hamilton, text ed. Hiroshi Yamashita and Toshiyuki Suzuki, rev. 2nd ed. (Harlow, UK: Pearson Longman, 2007); The Poetical Works of Edmund Spenser, ed. J. C. Smith and Ernest de Sélincourt (1912; repr., London: Oxford University Press, 1960); Edmund Spenser: The Shorter Poems, ed. Richard McCabe (Harmondsworth, UK: Penguin, 1999); and The Works of Edmund Spenser: A Variorum Edition, ed. Edwin Greenlaw et al., 11 vols. (Baltimore: Johns Hopkins University Press, 1932-57), this last for its analyses of the plan and conduct of each book of The Faerie Queene and for its invaluable selections of Spenser criticism from the eighteenth to the earlier twentieth centuries. For references to Spenser's fascinating prose work A View of the Present State of Ireland (composed around 1595, not published until 1633), currently being edited by Elizabeth Fowler, I have used the tenth volume of the Variorum edition but modernized spelling and punctuation (hence View, not Vewe). I have also consulted W. L. Renwick's notes, in A View of the Present State of Ireland by Edmund Spenser (1934; repr., Oxford, UK: Clarendon, 1970); for specialists an indispensable modern edition is that of Andrew Hadfield and Willy Maley, Edmund Spenser: A View of the Present State of Ireland (Oxford: Oxford University Press, 1997). I have not, however, modernized spelling and punctuation of the other prose work by Spenser cited often in this study: the Letter to Raleigh, which 
accompanied the first installment (1590) of The Faerie Queene but was not printed with the second installment (1596). "A Letter of the Authors expounding his whole intention in the course of this worke: which for that it giveth great light to the Reader, for the better understanding is hereunto annexed." In modern editions, as in the folio edition of The Faerie Queene that appeared in 1609, a decade after the poet's death, the Letter to Raleigh follows the seventh book of The Faerie Queene and is brief enough not to require more detailed citation. In the Hamilton edition it appears on pp. 714-18; in the Smith and De Selincourt edition, pp. 407-8. For quotations of Spenser's poetry I make the usual, modern adjustments of $j$ to $i$ and $v$ to $u$. I also supply a grave accent for final -èd when this syllable is sounded. Although I have been conservative in preserving punctuation and capitalizations, I have trusted common sense in places where these are merely obtrusive, for example, when a comma is placed at the end of a line before an enjambment. A new, multivolume edition of all Spenser's works is being prepared by Oxford University Press, the first since the Variorum.

Recent statistical analyses of Spenser's orthography suggest it does not vary so far as was formerly supposed from the norm in his day (when spelling was not formally standardized). Such results may justify some modernization in the future. Care must still be used because Spenser did alter the spelling of words to draw out secondary meanings and to enliven what he supposed to be deeper etymological truths, on the very freewheeling model of Plato's Cratylus. For this aspect of Spenser's poetry see what is one of the most widely cited articles on Spenser in the past half century, Martha Craig's "The Secret Wit of Spenser's Language," in Elizabethan Poetry: Modern Essays in Criticism, ed. Paul J. Alpers (New York: Oxford University Press, 1967), pp. 447-72. See also Catherine Nicholson, "Old Spelling and the Forging of Spenser's Readers,” Modern Language Quarterly 78, no. 2 (2017): 173-204; and Dorothy Stephens, "Spenser's Language(s): Linguistic Theory and Poetic Diction," in The Oxford Handbook of Edmund Spenser, ed. Richard A. McCabe (Oxford: Oxford University Press, 2010), chap. 20. Such Cratylan etymologizing was accomplished by spelling a word so that older and more venerable meanings, usually from ancient Greek and Latin, could show through. 
If Spenser's orthography is not so exceptional as was once supposed, his use of ostentatiously archaic language is indeed a mark of his style, as was noted by contemporaries no less judicious than Sir Philip Sidney and Ben Jonson, neither of whom approved. It is not always easy to distinguish between conventional orthography and enriched semantic reference for the sake of what Catherine Nicholson, in Uncommon Tongues: Eloquence and Eccentricity in the English Renaissance (Philadelphia: University of Pennsylvania Press, 2014), has called "innovative strangeness." In striving to enrich the word itself for further meaning, however, Spenser was not striving for newness-innovation was not a positive word in his day-but for connection with the past. That connection was in the first place intended to be with the English poetic tradition reaching back two centuries to the poet's acknowledged master, Chaucer, whom he called a "well of English undefyled" (FQ IV.ii.32). But, as mentioned, Spenser was also striving for enrichment by the ancient languages, by the ancient epic poets, Homer and Virgil, and by philosophers, especially Aristotle, whom the poet would have studied at Cambridge - and of course Plato, the philosopher of poets.

In the twentieth century such resonant use of language became common in poetry again, as it did in the philosophical writings of Martin Heidegger and the prose works of James Joyce, especially Finnegans Wake, surely the most intensely etymological creative work ever. Spenser, however, was the first English poet to do this, and it is at the level of language-language understood as still being haunted by long-occluded, residual meanings - that he was the father of Milton. Such a use of language is obviously well suited to the kind of active reading that is encouraged by allegory, as urged by Maureen Quilligan in The Language of Allegory: Defining the Genre (Ithaca, NY: Cornell University Press, 1979). Shortly after it appeared I had the good fortune to read Margot Norris, The Decentered Universe of "Finnegans Wake" (Baltimore: Johns Hopkins University Press, 1976). Worth consulting separately is Norris's "The Consequence of Deconstruction: A Technical Perspective of Joyce's Finnegans Wake," ELH 41, no. 1 (1974): 130-48. It is not only in this matter of a destabilized language that in striving to be more ancient and original than his contemporaries Spenser was actually being more modern. 
Another reason to use caution when modernizing the text of The Faerie Queene is that Spenser appears to have collaborated with the printersas he did formerly with The Shepheardes Calender - to manage the appearance of the poem on the page. As splendid as Spenser's acoustical effects are- the famous "music" of his verse-his two greatest works are meant also for the eye, something that cannot be said either of Shakespeare or of Milton, hence the elegant layout of the individual stanzas of The Faerie Queene-the middle seven lines of each stanza being carefully indented - the ornamental framing of the ballad-measure canto-headings, which are in italics, and the Letter to Raleigh.

Spenser scholarship following the Variorum edition of the 1930s has been most helpfully organized and abstracted in Foster Provost and Waldo F. McNeir's Edmund Spenser: An Annotated Bibliography, 1937-1972 (Pittsburgh: Duquesne University Press, 1975). For work after 1972, see the running annotated bibliography in Spenser Newsletter, later the Spenser Review, which continues to this day.

Like all Spenserians I make frequent use of the monumental Spenser Encyclopedia, ed. A. C. Hamilton et al. (Toronto: University of Toronto Press, 1990). The same is true for Andrew Hadfield's Edmund Spenser: A Life (Oxford: Oxford University Press, 2012), a work that will have changed the field of Spenser studies more than we can know at the present. I recommend Willy Maley's A Spenser Chronology (Basingstoke, UK: Macmillan; Lanham, MD: Barnes and Noble, 1994). I have long been and am today grateful for the online Spenser Review and its predecessor, the Spenser Newsletter, most recently edited by David Lee Miller, now by Jane Grogan and Andrew Hadfield; and for the regular volumes of Spenser Studies, recently edited by Andrew Escobedo and now by Susannah Monta and Bill Oram.

References to The Faerie Queene (abbreviated FQ in citations) are in traditional form, denoting books in Roman upper-case numerals, cantos in Roman lower-case numerals, and stanzas by Arabic number. For example, III.ii.4 means Book Three, canto two, stanza four. For proems, the word "proem" appears where lower-case Roman numerals otherwise would, for example, II.proem.2. The word proem, denoting the introductory passages to each book of The Faerie Queene, is not used by Spenser himself and began to be applied to these passages in the eighteenth

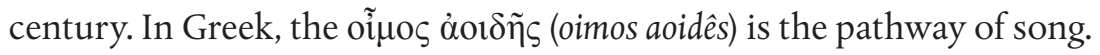


A prooimion, literally a preface, is that which comes before or leads into a pathway or a road, the image of a long road and meandering path being one Spenser used of his own work. See the first stanza of the proem to Book Six, beginning, "The waies, through which my weary steps I guyde, / In this delightfull land of Faery."

References to The Shepheardes Calender are by month and line number. 

Ich hatte nichts und doch genug:

Den Drang nach Wahrheit und die Lust am Trug.

I had nothing and yet enough:

the urge toward truth and the delight in illusion.

—Johann Wolfgang von Goethe

Denken ist nicht die geistige Reproduktion dessen, was ohnehin ist.... Offenes Denken weist über sich hinaus.

Thinking is not the mental copying of what already exists.... Open thinking points beyond itself.

-T. W. Adorno 

SPENSERIAN
MOMENTS 
